\title{
ANALISIS VECTOR AUTO REGRESSIVE (VAR) TERHADAP KORELASI ANTARA BELANJA PUBLIK DAN PERTUMBUHAN EKONOMI DI SULAWESI SELATAN, TAHUN 1985-2005
}

\author{
Abustan ${ }^{1}$ \\ Mahyuddin ${ }^{1}$ \\ ${ }^{1}$ Sekolah Pascasarjana Institut Pertanian Bogor \\ E-mail: abustan64@yahoo.co.id
}

\begin{abstract}
Vector Auto Regression (VAR) is an analysis or statistic method which can be used to predict time series variable and to analyst dynamic impact of disturbance factor in the variable system. In addition, VAR analysis is very useful to assess the interrelationship between economic variables. This research through the following test phases: unit root test, test of hypothesis, Granger causality test, and form a vector autoregresion model (VAR). The data used in this research is the GDP data and budget data of South Sulawesi in the period 1985-2004. The research aims to analyze the interrelationship between public expenditure and economic growth in South Sulawesi. The result showed statistically significant in economic growth $(P D R B)$ influence public expenditure (APBD), however, not vice versa. Otherwise, for the need of $A P B D$ prediction, the used of lag 4 was the optimum model based on the causal relationship to PDRB.
\end{abstract}

Keywords: hubungan kausalitas, belanja publik, pertumbuhan ekonomi, Vector Auto Regression (VAR) analysis

\section{PENDAHULUAN}

Dalam teori ekonomi pembangunan diketahui bahwa tingkat pertumbuhan ekonomi dan pengeluaran pemerintah mempunyai hubungan timbal balik yang positif. Aliran Keynesian menunjukkan bahwa pembelanjaan pemerintah memacu pertumbuhan ekonomi. Pandangan ini menjelaskan bahwa dengan meningkatnya pengeluaran pemerintah akan mendorong peningkatan permintaan berbagai barang dan jasa yang diproduksi perekonomian secara agregat, sehingga mendorong pertumbuhan perekonomian. Jadi, pengeluaran pemerintah dipandang sebagai kekuatan eksogenus yang mengubah output agregat. Dengan kata lain, dalam kasus ini pertumbuhan ekonomi merupakan fungsi dari pengeluaran pemerintah. Sebaliknya, Hukum Wagner "hukum meningkatnya ekspansi aktivitas publik" menekankan bahwa pertumbuhan ekonomi sebagai determinan utama pertumbuhan sektor publik (Wagner, 1983 dalam Mankiw, 2007 dan Donrbusch, et,al, 1987) yang berarti pengeluaran pemerintah merupakan fungsi dari pertumbuhan ekonomi. Analogi untuk hubungan ini adalah dengan meningkatnya pertumbuhan ekonomi, maka tingkat penerimaan pemerintah dari sektor pajak juga 
meningkat yang akhirnya meningkatkan pengeluaran pemerintah. Selain itu pertumbuhan ekonomi yang tinggi juga mencerminkan semakin besarnya kebutuhan layanan jasa pemerintah, sehingga dibutuhkan anggaran pemerintah yang semakin besar pula.

Implikasi kebijakan dari adanya hubungan timbal balik antara tingkat pengeluaran pemerintah dan tingkat pertumbuhan ekonomi tersebut adalah pada pembuatan proyeksi/ perkiraan kebutuhan anggaran pembangunan tahunan dan target pertumbuhan ekonomi. Dengan memegang asumsi bahwa hubungan timbal balik tersebut terjadi, maka dalam membuat proyeksi pengeluaran pemerintah harus memperhitungkan variabel pertumbuhan ekonomi; dan sebaliknya dalam memproyeksikan angka pertumbuhan ekonomi, variabel pengeluaran pemerintah harus dijadikan salah satu faktor penentu.

Hubungan kausalitas secara timbal balik seperti yang digambarkan memang secara teoritis memungkinkan, namun faktanya seringkali hanya merupakan hubungan satu arah saja. Oleh karena itu, kajian ini ditujukan untuk menguji hubungan kausalitas antara PDRB dan Belanja pemerintah (APBD) di Sulawesi Selatan apakah terjadi secara timbal balik atau satu arah saja (hanya PDRB mempengaruhi APBD atau hanya APBD mempengaruhi PDRB). Dengan memahami hubungan kausalitas tersebut, maka kajian ini diharapkan dapat melahirkan model proyeksi opitimal berdasarkan hubungan kausalitas yang ada, melalui model analisis vector auto regression (VAR).

Dengan mengamati data deret waktu selama dua dekade terakhir (1985-2005) dimana pertumbuhan ekonomi Sulawesi Selatan menunjukkan pertumbuhan yang cukup menggembirakan dengan rata-rata mencapai sekitar 5,94 persen pertahun, melampaui kinerja pertumbuhan ekonomi nasional yang hanya tumbuh sekitar 4,74 persen per tahun dalam periode yang sama, juga lebih tinggi dari rata-rata pertumbuhan ekonomi kawasan KTI (5,25 persen per tahun). Sementara di sisi lain kinerja belanja publik (pengeluaran pemerintah) Sulawesi Selatan yang diukur dari APBD Provinsi plus APBD kabupaten/kota se Sulawesi Selatan, juga memiliki tingkat pertumbuhan yang cukup tinggi yang pada nilai aktualnya tumbuhan rata-rata 22,51 persen pertahun. Berdasarkan gambaran kinerja dua variabel makro ekonomi Sulawesi Selatan tersebut, maka pertanyaan mendasarnya adalah apakah APBD Sulawesi Selatan yang setiap tahunnya hanya berkontribusi rata-rata 8,92 persen terhadap PDRB mampu menjadi variabel determinan yang signifikan terhadap pertumbuhan ekonomi Sulawesi Selatan, atau justru kinerja pertumbuhan Sulawesi Selatan yang menjadi faktor penentu terhadap tingginya pertumbuhan belanja publik (APBD) di daerah ini. Atau bisa jadi kedua variabel makro ekonomi tersebut memiliki hubungan kausalitas secara timbal balik, membentuk hubungan yang bersinergi sehingga keduanya memiliki kenerja yang cukup mengesankan. Lebih lanjut pertanyaannya adalah bagaimana bentuk hubungan kausalitas dari kedua variabel tersebut, sehingga dapat digunakan untuk melakukan proyeksi kinerja kedua variabel ini berdasarkan hubungan kausalitasnya. Berdasarkan hal tersebut maka rumusan permasalahan yang ingin dijawab dalam studi ini adalah:

1. Apakah PDRB Sulawesi Selatan secara signifikan mempengaruhi APBD Sulawesi Selatan?. 
2. Apakah APBD Sulawesi Selatan secara signifikan mempengaruhi PDRB Sulawesi Selatan?.

3. Apakah keduanya menunjukkan hubungan satu arah atau memiliki pengaruh secara timbal balik (dua arah)?.

4. Bagaimana model persamaan yang baik untuk melakukan proyeksi nilai PDRB atau APBD Sulawesi Selatan beberapa periode ke depan, berdasarkan hubungan kausalitasnya?.

Tujuan utama dari analisis ini adalah mengevaluasi secara empiris keterkaitan hubungan sebab akibat antara besaran belanja pemerintah pada sektor publik dan pertumbuhan ekonomi (PDRB) dalam model bivariat. Secara khusus tulisan ini akan melakukan (1) pengujian unit root terhadap variabel belanja publik (APBD) dan variabel PDRB, (2) pengujian kausalitas Granger antara APBD dan PDRB di Sulawesi Selatan, (3) mendapatkan model vektor Auto Regressive (VAR) yang sesuai untuk memproyeksi kebutuhan belanja publik (APBD) dan target pertumbuhan ekonomi beberapa periode ke depan, berdasarkan hubungan kausalitasnya.

1. Teori Pertumbuhan Ekonomi dan Belanja Pemerintah

Teori yang membahas mengenai hubungan pengeluaran pemerintah dengan pertumbuhan ekonomi diuraikan panjang lebar dalam The General Theory Keynes. Teori ini menguraikan bahwa pendapatan total perekonomian dalam jangka pendek, sangat ditentukan oleh keinginan rumah tangga, perusahaan dan pemerintah untuk membelanjakan pendapatannya. Untuk memodelkan pandangan Keynesian mengenai pengaruh pengeluaran pemerintah terhadap pertumbuhan ekonomi ini diilustrasikan dengan pemodelan yang disebut perpotongan Keynesian (Mankiw, 2007), seperti yang ditunjukkan pada gambar 1 .

Besarnya kenaikan output sebagai dampak dari kenaikan pengeluaran pemerintah disebut pengganda pembelian pemerintah (Government purchases multiplier) yang diukur dengan rasio $\Delta \mathrm{Y} / \Delta \mathrm{G}$. Implikasi

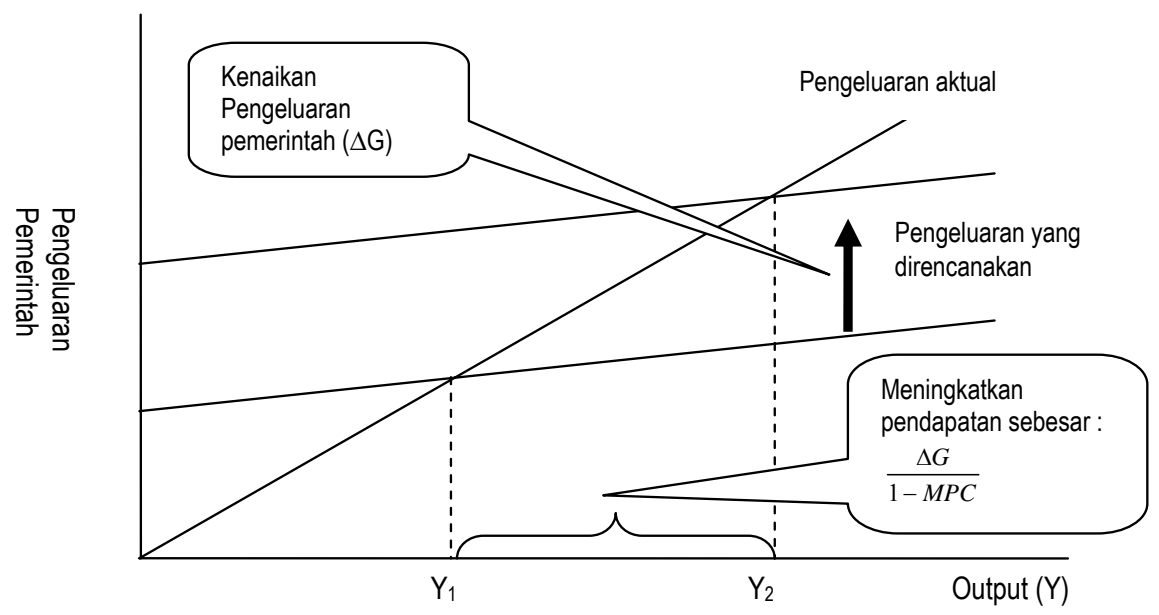

Gambar 1. Perpotongan Keynesian, Pergeseran ke atas dalam Pengeluaran Pemerintah yang Direncanakan Sebesar $\Delta \mathbf{G}$ Meningkatkan Output Sebesar $\Delta$ G/(1-MPC) 
dari perpotongan Keynesian adalah bahwa kenaikan output $(\Delta \mathrm{Y})$ lebih besar dari kenaikan pengeluaran pemerintah $(\Delta \mathrm{G})$, hal ini di sebabkan karena adanya efek berantai yang ditimbulkan dari peningkatan pengeluaran pemerintah. Proses ini bermula dari perubahan awal pengeluaran pemerintah sebesar $\Delta \mathrm{G}$ meningkatkan output $\Delta \mathrm{Y}$ sebesar $\Delta \mathrm{G}$, peningkatan output atau pendapatan ini selanjutnya meningkatkan konsumsi masyarakat sebesar MPC x $\Delta \mathrm{G}$, di mana MPC (Marginal Propensity to Consume) adalah kecenderungan mengkonsumsi marginal. Kenaikan dalam pendapatan yang kedua ini sekali lagi meningkatkan konsumsi sekarang sebesar MPC x (MPC x $\Delta \mathrm{G})$ dan seterusnya, sehingga angka pengganda ini merupakan seri geometri tidak terhingga. Secara aljabar pengganda pemerintah ini dapat dituliskan:

$$
\begin{aligned}
& \frac{\Delta Y}{\Delta G}=1+M P C+M P C^{2}+M P C^{3}+\ldots \\
& \frac{\Delta Y}{\Delta G}=1 /(1-M P C)
\end{aligned}
$$

Selanjutnya menurut (Loizides, et, al, 2005) menunjukkan bahwa pertumbuhan substansial dari besaran pengeluaran pemerintah baik di negara maju maupun pada negara berkembang ini sejak Perang Dunia II, dan pengaruhnya pada pertumbuhan ekonomi jangka panjang (atau sebaliknya), telah banyak menjadi subyek penelitian. Di sisi lain, studi pembiayaan publik telah diarahkan untuk mengidentifikasikan penyebab pertumbuhan sektor publik. Hukum Wagner mengenai pengeluaran publik adalah salah satu usaha paling awal yang menekankan pertumbuhan ekonomi sebagai determinan mendasar dari pertumbuhan sektor publik. Sejumlah studi menemukan hubungan positif yang nyata antara pertumbuhan sektor publik dan pertumbuhan ekonomi hanya untuk negara berkembang tetapi bukan pada negara maju, yang lainnya malahan melaporkan hubungan negatif antara pembelanjaan pemerintah dan GNP.

\section{Teori Ekonometrika}

Vector Auto Regression (VAR) biasanya digunakan untuk memproyeksikan sistem variabel-variabel runtut waktu dan untuk menganalisis dampak dinamis dari faktor gangguan yang terdapat dalam sistem variabel tersebut. Pada dasarnya Analisis VAR bisa dipadankan dengan suatu model persamaan simultan, oleh karena dalam analisis VAR kita mempertimbangkan beberapa variabel endogen secara bersama-sama dalam suatu model. Perbedaannya dengan model persamaan simultan biasa adalah bahwa dalam analisis VAR masing-masing variabel selain diterangkan oleh nilainya di masa lampau, juga dipengaruhi oleh nilai masa lalu dari semua variabel endogen lainnya dalam model yang diamati. Di samping itu, dalam analisis VAR biasanya tidak ada variabel eksogen dalam model tersebut (Nachrowi, 2006; Pindyck, dkk 1998; Verbeck, M, 2000).

Keunggulan dari analisis VAR antara lain adalah: (1) Metode ini sederhana, kita tidak perlu khawatir untuk membedakan mana variabel endogen, mana variabel eksogen; (2) Estimasinya sederhana, dimana metode OLS biasa dapat diaplikasikan pada tiap-tiap persamaan secara terpisah; (3) Hasil perkiraan (forecast) yang diperoleh dengan menggunakan metode ini dalam banyak kasus lebih bagus dibandingkan dengan hasil yang didapat dengan menggunakan model 
persamaan simultan yang kompleks sekalipun. Selain itu, analisis VAR juga merupakan alat analisis yang sangat berguna, baik di dalam memahami adanya hubungan timbal balik (interrelationship) antara variabelvariabel ekonomi, maupun di dalam pembentukan model ekonomi berstruktur.

\section{Penelitian Terdahulu}

Aplikasi model VAR untuk melihat interrelationship antar variabel pertumbuhan ekonomi dan investasi pemerintah di Indonesia telah dilakukan oleh Hadi, Y. S. (2003). Studi ini menggunakan data series nasional dalam kurun waktu 1983/1984 hingga 1999/2000 dan menunjukkan bahwa dalam periode yang diamati, investasi pemerintah di sektor fiskal, khususnya pengeluaran pembangunan rupiah ternyata tidak mempunyai pengaruh yang signifikan terhadap pertumbuhan ekonomi. Temuan ini menunjukkan bahwa sebagaimana menurut aliran Klasik terdapat dichotomy antara sektor riil dan sektor moneter, dalam studi ini juga ditemukan antara dichotomy antara sektor riil dan sektor fiskal di Indonesia. Alasan yang mungkin bisa digunakan untuk menjelaskan hal ini adalah bahwa dalam penyusunan rencana APBN, pembiayaan rupiah diperlakukan sebagai residu, dan tidak dikaitkan dengan besarnya kebutuhan investasi dalam pertumbuhan ekonomi, namun tergantung kepada ketersediaan dana yang ada. Pengeluaran pembangunan rupiah ini identik dengan tabungan pemerintah yang notabene merupakan selisih antara penerimaan dalam negeri dengan pengeluaran rutin. Dalam kondisi seperti ini, hubungan yang tidak signifikan antara pembiayaan rupiah dengan PDB merupakan hal yang masuk akal. Tidak signifikannya hubungan antara pembiayaan rupiah dengan pertumbuhan ekonomi secara statistik juga bisa memberikan indikasi lain, yaitu bahwa pertumbuhan ekonomi lebih ditentukan oleh faktor-faktor lain, di luar investasi pemerintah.

Kebijakan otonomi daerah merupakan pendelegasian kewenangan yang disertai dengan penyerahan dan pengalihan pendanaan, sarana dan prasarana serta sumber daya manusia (SDM) dalam kerangka desentralisasi fiskal. Dalam menghadapi desentralisasi fiskal menunjukkan bahwa potensi fiskal pemerintah daerah antara satu dengan daerah yang lain bisa jadi sangat beragam. Perbedaan ini pada gilirannya dapat menghasilkan pertumbuhan ekonomi yang beragam pula.

Pertumbuhan ekonomi adalah proses kenaikan output per kapita (Boediono, 1985). Secara tradisional, pertumbuhan ekonomi ditujukan untuk peningkatan yang berkelanjutan pada Produk Domestik Regional Daerah/PDRB (Saragih, 2003; Kuncoro, 2004). Hasil penelitian yang dilakukan Lin dan Liu (2000) menunjukkan desentralisasi memberikan dampak yang sangat berarti bagi pertumbuhan ekonomi daerah. Oates (1995), Lin dan Liu (2000) yang membuktikan adanya hubungan yang positif dan signifikan antara desentralisasi fiskal dengan pertumbuhan ekonomi. Hasil ini mendukung sintesa yang menyatakan bahwa, pemberian otonomi yang lebih besar akan memberikan dampak yang lebih besar bagi pertumbuhan ekonomi, hal inilah yang mendorong daerah untuk mengalokasikan secara lebih efisien berbagai potensi lokal untuk kepentingan pelayanan publik (Lin dan Liu, 2000; Mardiasmo, 2002; Wong, 2004).

Louizides, menggunakan data tahunan dari UK, Yunani, dan Irlandia, paper ini mengkaji hubungan antara besaran pertum- 
buhan pemerintah dan pertumbuhan pendapatan pada sistem bivariate dan trivariate, berdasarkan pada analisis kointegrasi, strategi ECM dan uji kausalitas Granger. Berdasarkan hasil empiris yang didapat, muncul kesimpulan sebagai berikut. Pertama, pada ketiga negara penyebab pertumbuhan Granger pengeluaran publik adalah pendapatan nasional baik dalam jangka pendek maupun jangka panjang, dihasilkan baik dalam analisis bivariate maupun trivariate. Analisis ini secara umum menilai hipotesis bahwa ekspansi publik adalah menghambat pertumbuhan ekonomi di negara tersebut. Tingkat pertumbuhan yang mendasarinya yang berdampak pada sektor publik adalah positif, yang berarti bahwa pembelanjaan publik mendukung pembangunan ekonomi. Kedua, Yunani menunjukkan dukungan pada hipotesis Wagner yaitu kenaikan output menyebabkan pertumbuhan pada pengeluaran publik. Ini nampak pada uji bivariate dan juga trivariate. Ketiga, data Inggris juga menunjukkan pola serupa jika model trivariate (dengan inflasi sebagai variabel tambahan) digunakan. Sebaliknya, hasil untuk Irlandia tidak menunjukkan pengaruh kausalitas tipe Wagnerian. Terakhir, disebutkan bahwa meskipun variabel potensial lainnya seperti suku bunga riil atau hutang publik terhadap GNP belum dieksplorasi, studi ini mengindikasikan kemungkinan dimensionalitas hubungan makro antara pendapatan perkapita riil dan besaran sektor publik.

\section{METODE PENELITIAN}

\section{Data}

Data yang digunakan dalam kajian ini adalah data tahun PDRB dan APBD Sulawesi Selatan dari tahun 1985-2004. Data PDRB adalah data PDRB menurut Harga konstan 2000. Sedangkan APBD merupakan penjumlahan antara APBD provinsi Sulawesi Selatan dan jumlah APBD Kabupaten/kota se Sulawesi Selatan yang dideflasi menurut Indek harga konsumen (IHK) tahun 2000. Perkembangan nilai dari dua variabel yang akan diuji kausalitasnya ditunjukkan pada gambar 2.

\section{Model Empiris}

Seperti yang sudah dijelaskan bahwa Vector Auto Regression (VAR) merupakan salah satu alat analisis yang tidak saja berguna untuk melihat hubungan kausalitas antara variabel, tapi juga dapat digunakan untuk menentukan model proyeksi. Untuk memahami analisis VAR, model secara empiris diilustrasikan sebagai berikut:

$$
\begin{aligned}
Y_{t}= & a_{10}+a_{11} Y_{t-1}+a_{12} Z_{t-1}+a_{13} Y_{t-2}+ \\
& a_{14} Z_{t-2}+e_{y t} \\
Z_{t}= & a_{20}+a_{21} Y_{t-1}+a_{22} Z_{t-1}+a_{23} Y_{t-2}+ \\
& a_{24} Z_{t-2}+e_{z t}
\end{aligned}
$$

dimana:

$$
\begin{aligned}
& \mathrm{Y}_{\mathrm{t}}=\text { PDRB pada tahun } \mathrm{t} \\
& \mathrm{Z}_{\mathrm{t}}=\text { APBD pada tahun } \mathrm{t} \\
& \mathrm{Y}_{\mathrm{t}-\mathrm{n}}=\text { PDRB pada tahun } \mathrm{t}-\mathrm{n} \\
& \mathrm{Z}_{\mathrm{t}-\mathrm{n}}=\text { APBD pada tahun } \mathrm{t}-\mathrm{n} \\
& \mathrm{a}_{10}, \mathrm{a}_{20}=\text { konstanta } \\
& \mathrm{e}_{\mathrm{yt}}, \mathrm{e}_{\mathrm{zt}}=\text { faktor gangguan }
\end{aligned}
$$

Dua persamaan di atas menunjukkan bahwa dua variabel ekonomi yang diamati, yakni produk domestik regional bruto (PDRB) dan APBD, saling mempengaruhi satu sama lain. Sebagai contoh, PDRB dalam 


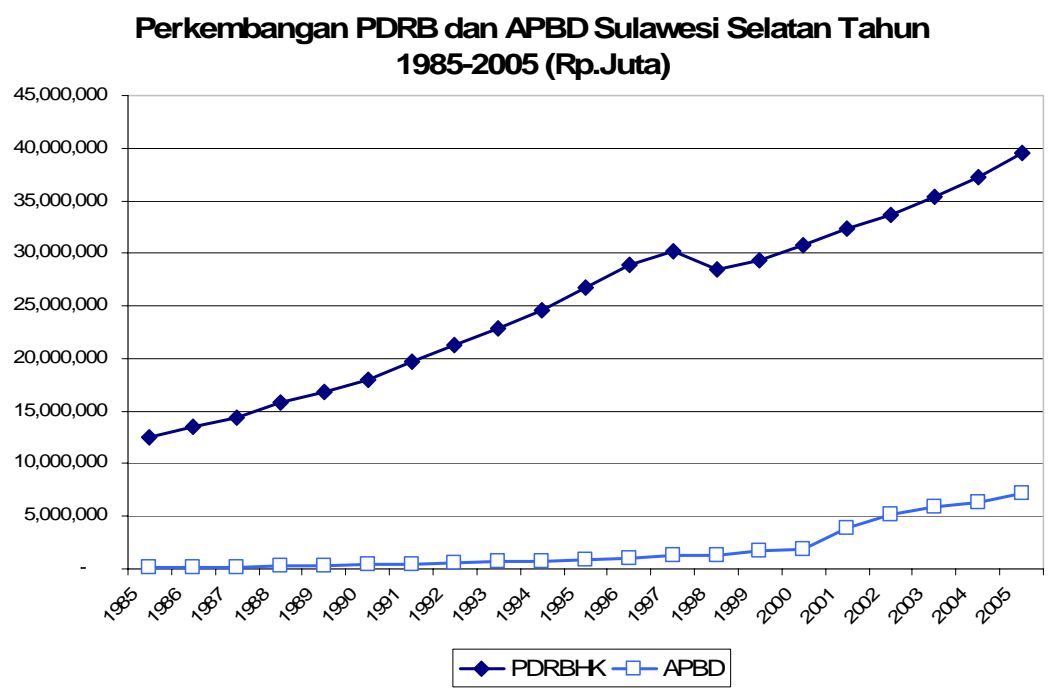

\section{Gambar 2. Perkembangan Nilai PDRB Harga Konstan Sulawesi Selatan dan APBD Sulawesi Selatan dari Tahun 1985-2005}

tahun $t\left(\mathrm{Y}_{\mathrm{t}}\right)$ dipengaruhi oleh PDRB dalam periode sebelumnya $\left(\mathrm{Y}_{\mathrm{t}-1}\right.$ dan $\left.\mathrm{Y}_{\mathrm{t}-2}\right)$, dan oleh APBD dalam tahun sebelumnya $\left(Z_{t-1}\right.$ dan $\mathrm{Z}_{\mathrm{t}-2}$ ). Demikian pula, APBD dalam tahun $\mathrm{t}$ $\left(Z_{t}\right)$ dipengaruhi oleh APBD dalam tahun sebelumnya $\left(Z_{t-1}\right.$ dan $\left.Z_{t-2}\right)$, dan oleh PDRB dalam periode sebelumnya $\left(\mathrm{Y}_{\mathrm{t}-1}\right.$ dan $\left.\mathrm{Y}_{\mathrm{t}-2}\right)$.

\section{Metode Analisis}

Dalam rangka menguji kausalitas antara PDRB dan APBD Sulawesi Selatan dengan metode VAR, maka beberapa tahapan analisis pengujian sebagai berikut, di mana semua tahapan dalam analisis ini menggunakan software Eviews 4.1.:

\section{Uji akar unit (Unit Root Test)}

Uji akar unit ini digunakan untuk melihat apakah data yang diamati stationer atau tidak. Test ini sebenarnya hanya merupakan pelengkap dari analisis VAR, mengingat tujuan dari analisis VAR adalah untuk menilai adanya hubungan timbal balik di antara variabel-variabel yang diamati, dan bukan test untuk data. Akan tetapi, apabila data yang diamati adalah stationer, hal ini akan meningkatkan akurasi dari analisis VAR (Juanda, 2008; Nachrowi, 2006; dan Verbeek, 2006).

Model pengujian unit root pada variabel PDRB dan APBD adalah menggunakan model pengujian Augmented Dickey-Fuller Test (ADF Test), di mana model ini mengasumsikan bahwa $\varepsilon_{t}$ dari $\Delta Y_{t}=\delta Y_{t-1}+\varepsilon_{t}$ adalah independently dan identical distributed (IID) variabel acak, dengan nilai rataan nol dan varians $\sigma^{2}$ konstan. Jika $\delta=0$, maka $\varepsilon_{t}$ adalah IID atau mempunyai unit root, dan data time series yang memiliki unit root disebut data non-stationary. Data time series dikatakan tidak mengandung unit root 
atau bersifat stationer jika nilai statistik ADF test lebih besar dari nilai kritis 10 persen.

\section{Uji Hipotesis (Hyphothesis Testing) Cau- salitas Granger (Granger Causality Test)}

Dalam rangka membentuk model VAR antara PDRB dan APBD Sulawesi Selatan, maka metode analisis untuk melihat hubungan kausalitas antara variabel tersebut digunakan Uji Kausalitas Granger, di mana bentuk hubungan kausalitas Granger yang dimodelkan adalah:

$$
P D R B_{t}=\sum a_{i} A P B D_{t-i}+\sum b_{i} P D R B_{t-j}+u_{i t}
$$

dan

$$
A P B D_{t}=\sum c_{i} A P B D_{t-i}+\sum d_{i} P D R B_{t-j}+u_{i t}
$$

di mana

$$
\begin{aligned}
P_{t R B_{t}=} & \text { PDRB Sulawesi Selatan pada } \\
& \text { tahun } \mathrm{t}(\mathrm{IHK} 2000=100) \\
P D R B_{t-j}= & \text { PDRB Sulawesi Selatan pada } \\
& \text { tahun sebelumnya ke-j (IHK } \\
& 2000=100) \\
A P B D_{t}= & \text { APBDProvinsi }+ \text { APBD Kabu- } \\
& \text { paten/ Kota se Sulawesi Sela- } \\
& \text { tan pada tahun t di deflasi } \\
& \text { dengan IHK (2000=100) } \\
= & \text { APBD Provinsi }+ \text { APBD Kabu- } \\
& \text { paten } / \text { Kota se Sulawesi Selatan } \\
\text { pada tahun sebelumnya ke- } i \text { di } & \text { deflasi dengan IHK (2000 }= \\
& 100) \\
& \text { Konstanta } \\
= & \text { faktor gangguan }
\end{aligned}
$$

Berdasarkan model regresi uji kausalitas Granger yang dimodelkan, maka hipotesis yang akan diuji adalah:

$\mathrm{H}_{0}$ : PDRB tidak mempengaruhi (tidak menyebabkan) APBD Sulawesi Sela$\tan$

$\mathrm{H}_{1}$ : PDRB mempengaruhi (menyebabkan) APBD Sulawesi Selatan

$\mathrm{H}_{0}$ : APBD tidak mempengaruhi (tidak menyebabkan) PDRB Sulawesi Sela$\tan$

$\mathrm{H}_{1}$ : APBD mempengaruhi (menyebabkan) PDRB Sulawesi Selatan

Jika nilai probabilitas dari kedua hipotesis di atas lebih kecil dari nilai kesalahan yang dapat ditolerir $(\alpha=0,05)$ maka keduanya diputuskan untuk menolak $\mathrm{H}_{0}$, sehingga interpretasinya adalah PDRB dan APBD Sulawesi Selatan saling mempengaruhi secara timbal balik. Akan tetapi jika hanya satu hipotesis $\mathrm{H}_{0}$ yang ditolak, berarti hubungan antara PDRB dan APBD hanya merupakan hubungan kausalitas yang satu arah.

\section{Model Vektor Otoregresi (VAR)}

Setelah melakukan uji kausalitas dengan metode Kausalitas Granger test, maka langkah selanjutnya adalah membentuk Model VAR. Jika ternyata berdasarkan hasil uji kausalitas pada persamaan (1) dan (2) menunjukkan hubungan yang saling mempengaruhi maka model VAR akan menjadi:

$$
\begin{array}{r}
P D R B=a_{1 i}+\sum \beta_{1 t} P D R B_{-i}+\sum \gamma_{1 t} A P B D_{t-i}+\varepsilon_{t} \\
\ldots \ldots(3)
\end{array}
$$

$$
A P B D=a_{2 i}+\sum \beta_{2 t} P D R B_{-i}+\sum \gamma_{2 t} A P B D_{-i}+\varepsilon_{t}
$$


Penentuan jumlah lag yang akan digunakan dalam menentukan model VAR adalah di dasarkan pada uji Akaike Information Criterion (AIC) dan Schwarz Information Criterion (SIC). Pengujian lag dilakukan di mulai dari Lag 2 dan berhenti pada lag yang lebih besar jika nilai AIC dan SIC sudah semakin kecil.

\section{HASIL PENELITIAN DAN PEMBAHASAN}

\section{Pengujian Unit root}

Dengan bantuan program Eviews 4.1, dilakukan Augmented Dickey-Fuller Test untuk melakukan uji akar unit (Unit Root Test) untuk menguji apakah variabel PDRB Sulawesi Selatan dan APBD Sulawesi Selatan bersifat stationer atau tidak. Dengan mencakup trend dan intercept, diperoleh hasil perhitungan bahwa untuk variabel PDRB harga konstan 2000 pada data level secara signifikan mengandung unit root, yang berati bahwa pada data level ini variabel PDRB Sulawesi Selatan tidak stationer. Derajat intgrasi pada variabel ini terjadi pada data second different, yang berarti bahwa PDRB Sulawesi Selatan bersifat stationer pada data second different, untuk jelasnya hasil pengujian uniit root variabel yang dianlisis berdasarkan metode Augmented DickeyFuller Test (ADF-Test) dapat dilihat pada tabel 2.

Pada tabel 2 terlihat pula bahwa untuk variabel APBD Sulawesi Selatan yang merupakan akumulasi dari APBD Provinsi plus APBD Kabupaten/kota se Sulawesi Selatan yang di deflasi menurut IHK tahun 2000 , terlihat bahwa variabel ini bersifat stationer pada data First different. Hasil pengujian unit root ini juga menghasilkan nilai Durbin-Watson statistik yang cukup baik yakni sebesar 2,05 pada data level dan 2,10 untuk second different pada variabel PDRB. Sedangkan untuk variabel APBD nilai statistik DW sebesar 1,94 pada data level dan 1,95 pada first different.

\section{Pengujian Kausalitas Granger}

Selanjutnya berdasarkan hasil pengujian kausalitas Granger menunjukkan bahwa nilai probabilitas pada pengujian APBD terhadap PDRB Sulawesi Selatan sebesar 0,77939, yang berarti pada tingkat kesalahan yang dapat ditolerir $\alpha=0,05$ hipotesis yang menyatakan APBD berpengaruh terhadap PDRB (H1) tidak dapat di terima dan menerima H0, dengan kata lain secara sifnifikan tidak berpengaruh terhadap PDRB. Sedangkan nilai probabilitas pada pengujian pengaruh PDRB terhadap APBD menunjukkan nilai probabilitas sebesar 0,00032 , yang berarti pada tingkat kepercayaan 99 persen, hipotesis yang menyatakan bahwa PDRB berpengaruh terhadap APBD (H1) dapat di terima dan menolak $\mathrm{H} 0$ yang berarti pula pertumbuhan ekonomi Sulawesi Selatan (PDRB) merupakan variabel determinan yang signifikan terhadap besarnya APBD. 
Tabel 2. Hasil Pengujian Unit root Data Level pada Variabel APBD Sulawesi Selatan

Null Hypothesis: D(PDRBHK,2) has a unit root

Exogenous: Constant, Linear Trend

Lag Length: 0 (Automatic based on SIC, MAXLAG=4)

\begin{tabular}{lccc}
\hline \hline & & t-Statistic & Prob. $^{*}$ \\
\hline \hline Augmented Dickey-Fuller test statistic & & -4.645059 & 0.0087 \\
\hline Test critical values: & $1 \%$ level & -4.571559 & \\
& $5 \%$ level & -3.690814 & \\
\hline \hline "MacKinnon (1996) one-sided p-values. & $10 \%$ level & -3.286909 & \\
\hline Null Hypothesis: D(APBDK) has a unit root & & & \\
Exogenous: Constant, Linear Trend & & & \\
Lag Length: 0 (Automatic based on SIC, MAXLAG=4) & & & Prob. ${ }^{*}$ \\
\hline \hline & & t-Statistic & 0.0347 \\
\hline \hline Augmented Dickey-Fuller test statistic & 1\% level & -3.873264 & \\
\hline Test critical values: & $5 \%$ level & -3.6732598 & \\
& $10 \%$ level & -3.277364 & \\
\hline \hline
\end{tabular}

*MacKinnon (1996) one-sided p-values.

Tabel 3. Hasil Kausalitas Grunger antara Variabel PDRB dan APBD Sulawesi Selatan

Pairwise Granger Causality Tests

Date: 07/16/08 Time: 12:29

Sample: 19852005

Lags: 4

\begin{tabular}{lccc}
\hline \hline Null Hypothesis: & Obs & F-Statistic & Probability \\
\hline \hline APBD does not Granger Cause PDRBHK & 17 & 0.43641 & 0.77939 \\
PDRBHK does not Granger Cause APBD & & 19.8758 & 0.00032 \\
\hline
\end{tabular}

Berdasarkan hasil pengujian kausalitas Granger seperti yang ditunjukkan pada tabel 2 terlihat bahwa hubungan kausalitas antara PDRB dan APBD Sulawesi Selatan tidak menunjukkan hubungan yang timbal balik (2 arah), tetapi hanya hubungan satu arah, di mana arah pengaruhnya adalah APBD merupakan fungsi dari PDRB dan tidak sebaliknya.

\section{Analisis Model Vektor Auto Regressive (VAR)}

Dalam membentuk model VAR, maka lebih lebih awal harus ditentukan dulu berapa jumlah lag yang paling sesuai dengan model. 
Untuk menentukan jumlah lag yang paling sesuai dengan model, maka kriteria yang di gunakan adalah di dasarkan pada nilai uji Akaike Information Criterion (AIC) dan Schwarz Information Criterion (SIC) yang menghasilkan nilai minimum. Hasil analisis menunjukkan bahwa nilai AIC dan SIC pada lag 4 menurun dan meningkat lagi pada lag 5. Dengan demikian jumlah lag yang paling sesuai dengan model adalah lag 4, dengan nilai AIC sebesar 58.56502 dan nilai SIC sebesar 59.44724. Pada lag 4 selain memiliki nilai AIC dan SIC minimum juga memiliki nilai R-squared yang lebih tingi dibandingkan mengguakan lag lainnya. Dengan demikian maka kesimpulannya adalah PDRB dan APBD memiliki hubungan kausalitas yang lebih baik pada lag 4 .

\section{Tabel 4. Penentuan Model VAR antara Variabel PDRB dan APBD Sulawesi Selatan}

\begin{tabular}{|c|c|c|c|c|c|c|}
\hline \multicolumn{7}{|c|}{$\begin{array}{l}\text { Vector Autoregression Estimates } \\
\text { Date: 07/08/08 Time: } 13: 21 \\
\text { Sample(adjusted): } 19892005 \\
\text { Included observations: } 17 \text { after adjusting } \\
\quad \text { endpoints } \\
\text { Standard errors in () \& t-statistics in [] }\end{array}$} \\
\hline & \multicolumn{2}{|c|}{$\operatorname{Lag}=4$} & \multicolumn{2}{|c|}{$\operatorname{Lag}=3$} & \multicolumn{2}{|c|}{$\operatorname{Lag}=2$} \\
\hline & PDRBHK & APBDK & PDRBHK & APBDK & PDRBHK & APBDK \\
\hline PDRBHK(-1) & $\begin{array}{r}1.238509 \\
-0.36222 \\
{[3.41918]}\end{array}$ & $\begin{array}{r}-0.15458 \\
-0.0554 \\
{[-2.79046]}\end{array}$ & $\begin{array}{r}1.279911 \\
-0.29231 \\
{[4.37862]}\end{array}$ & $\begin{array}{r}0.008827 \\
-0.21452 \\
{[0.04115]}\end{array}$ & $\begin{array}{r}1.227975 \\
-0.2537 \\
{[4.84019]}\end{array}$ & $\begin{array}{r}0.009648 \\
-0.17663 \\
{[0.05462]}\end{array}$ \\
\hline PDRBHK(-2) & $\begin{array}{r}-0.569345 \\
-0.57371 \\
{[-0.99239]}\end{array}$ & $\begin{array}{r}0.338874 \\
-0.08774 \\
{[3.86228]}\end{array}$ & $\begin{array}{r}-0.619624 \\
-0.45274 \\
{[-1.36862]}\end{array}$ & $\begin{array}{r}0.017015 \\
-0.33226 \\
{[0.05121]}\end{array}$ & $\begin{array}{r}-0.27449 \\
-0.24759 \\
{[-1.10865]}\end{array}$ & $\begin{array}{r}0.028473 \\
-0.17238 \\
{[0.16518]}\end{array}$ \\
\hline PDRBHK(-3) & $\begin{array}{r}0.195995 \\
-0.57491 \\
{[0.34091]}\end{array}$ & $\begin{array}{r}-0.656472 \\
-0.08792 \\
{[-7.46645]}\end{array}$ & $\begin{array}{r}0.284064 \\
-0.28184 \\
{[1.00788]}\end{array}$ & $\begin{array}{r}0.011635 \\
-0.20684 \\
{[0.05625]}\end{array}$ & & \\
\hline PDRBHK(-4) & $\begin{array}{r}0.066515 \\
-0.35259 \\
{[0.18865]}\end{array}$ & $\begin{array}{r}0.480131 \\
-0.05392 \\
{[8.90412]}\end{array}$ & & & & \\
\hline APBDK(-1) & $\begin{array}{r}-0.029251 \\
-0.59289 \\
{[-0.04934]}\end{array}$ & $\begin{array}{r}1.263582 \\
-0.09067 \\
{[13.9358]}\end{array}$ & $\begin{array}{r}-0.067343 \\
-0.48642 \\
{[-0.13845]}\end{array}$ & $\begin{array}{r}1.094493 \\
-0.35697 \\
{[3.06603]}\end{array}$ & $\begin{array}{r}-0.008762 \\
-0.40902 \\
{[-0.02142]}\end{array}$ & $\begin{array}{r}1.043112 \\
-0.28477 \\
{[3.66298]}\end{array}$ \\
\hline APBDK(-2) & $\begin{array}{r}0.405975 \\
-1.03626 \\
{[0.39177]}\end{array}$ & $\begin{array}{r}-0.553913 \\
-0.15848 \\
{[-3.49522]}\end{array}$ & $\begin{array}{r}0.454401 \\
-0.87119 \\
{[0.52159]}\end{array}$ & $\begin{array}{r}-0.24679 \\
-0.63935 \\
{[-0.38600]}\end{array}$ & $\begin{array}{r}0.285022 \\
-0.43345 \\
{[0.65756]}\end{array}$ & $\begin{array}{r}-0.03183 \\
-0.30178 \\
{[-0.10547]}\end{array}$ \\
\hline APBDK(-3) & $\begin{array}{r}-0.155874 \\
-1.04276 \\
{[-0.14948]}\end{array}$ & $\begin{array}{r}-0.258716 \\
-0.15947 \\
{[-1.62232]}\end{array}$ & $\begin{array}{r}-0.103078 \\
-0.73371 \\
{[-0.14049]}\end{array}$ & $\begin{array}{r}0.217235 \\
-0.53846 \\
{[0.40344]}\end{array}$ & & \\
\hline
\end{tabular}




\begin{tabular}{lrrrrrr} 
APBDK(-4) & 0.163678 & 1.168686 & & & & \\
& -1.15065 & -0.17597 & & & & \\
& {$[0.14225]$} & {$[6.64131]$} & & & & \\
C & & & & & & \\
& 2677609 & 376740.6 & 2319148 & -588451.4 & 1801289 & -588443 \\
& -1790067 & -273759 & -1260662 & -925179 & -1021080 & -710899 \\
& {$[1.49582]$} & {$[1.37617]$} & {$[1.83963]$} & {$[-0.63604]$} & {$[1.76410]$} & {$[-0.82774]$} \\
\hline \hline R-squared & 0.988306 & 0.99766 & 0.990043 & 0.947661 & 0.990474 & 0.948827 \\
Adj. R-squared & 0.976612 & 0.995321 & 0.984612 & 0.919112 & 0.987752 & 0.934206 \\
Sum sq. resids & $8.39 \mathrm{E}+12$ & $1.96 \mathrm{E}+11$ & $8.54 \mathrm{E}+12$ & $4.60 \mathrm{E}+12$ & $9.67 \mathrm{E}+12$ & $4.69 \mathrm{E}+12$ \\
S.E. equation & 1024265 & 156643.4 & 880892.1 & 646471.9 & 831213 & 578709.8 \\
F-statistic & 84.5139 & 426.4177 & 182.2986 & 33.19471 & 363.9215 & 64.89566 \\
Log likelihood & -252.9862 & -221.0643 & -267.505 & -261.9357 & -283.0409 & -276.1613 \\
Akaike AlC & 30.8219 & 27.06638 & 30.50056 & 29.88175 & 30.32009 & 29.59592 \\
Schwarz SC & 31.26301 & 27.5075 & 30.84681 & 30.228 & 30.56863 & 29.84446 \\
Mean dependent & 27989172 & 2293461 & 27313807 & 2180078 & 26633804 & 2074815 \\
S.D. dependent & 6697546 & 2289936 & 7101309 & 2273049 & 7510837 & 2256154 \\
\hline \hline Determinant Residual Covariance & $1.12 \mathrm{E}+22$ & & $3.05 \mathrm{E}+23$ & & $2.20 \mathrm{E}+23$ \\
Log Likelihood (d.f. adjusted) & -479.8026 & & -537.7524 & & -564.5153 \\
Akaike Information Criteria & 58.56502 & & 61.30583 & & 60.47529 \\
Schwarz Criteria & & 59.44724 & & 61.99834 & & 60.97237 \\
\hline \multicolumn{7}{l}{} \\
\hline
\end{tabular}

Berdasarkan hasil pengujian untuk menentukan model VAR dimana keputusan yang diambil didasarkan pada tingkat signifikansi pada kesalahan yang dapat ditolerir $\alpha=0,05$ yaitu dengan membandingkan nilai t-hitung (nilai pada baris ke tiga) dibandingkan dengan t-tabel di mana pada $\alpha=0,05$, nilai t-tabelnya sebesar 1,761 . Jika t-hitung lebih besar pada t-tabel maka dinyatakan berpengaruh secara signifikan. Berdasarkan hasil pengujian bahwa PDRB Sulawesi Selatan hanya dipengaruhi oleh PDRB pada t-1. Sedangkan nilai APBD dipengaruhi oleh PDRB pada t-1 dan PDRB pada t-4, APBD pada $\mathrm{t}-2$. Dengan demikian dalam rangka melakukan proyeksi PDRB ke depan maka variabel penentunya adalah PDRB pada t-1. Sedangkan dalam rangka memproyeksi APBD ke depan variabel maka variabel penentunya adalah APBD pada t-2 dan PDRB pada $t-1$ dan juga PDRB pada t-4 sebagai variabel determinannya. Oleh karena itu, untuk menggunakan model VAR dalam melakukan proyeksi PDRB dan APBD Sulawesi Selatan adalah dengan menggunakan model VAR pada Lag 4 dengan model seperti terlihat berikut ini: 


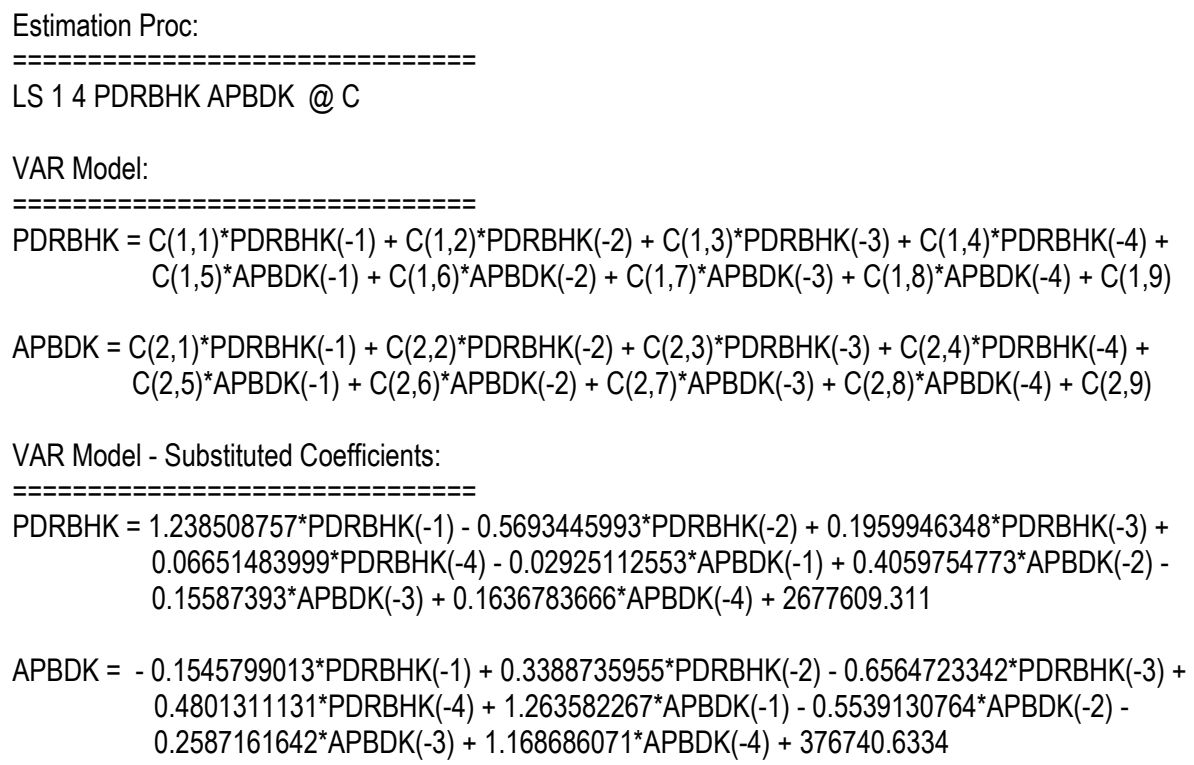

\section{KESIMPULAN}

Berdasarkan hasil pengujian dan pembahasan tersebut di atas maka dapat ditarik beberapa kesimpulan berikut:

1. Berdasarkan hasil pengujian unit root, menunjukkan bahwa variabel PDRB dan APBD Sulawesi Selatan pada data level tidak stationer atau mengandung unit root. Variabel PDRB menjadi stasioner pada data second different, sedangkan variabel APBD stasioner pada data first different.

2. Hubungan kausalitas antara PDRB dan APBD hanya satu arah yakni PDRB sebagai determinan terhadap APBD dan tidak sebaliknya. Berarti bahwa kinerja belanja publik tidak berdampak pada pertumbuhan ekonomi.

3. Pandangan Keynesian yang menyatakan bahwa pengaruh perubahan pengeluaran pemerintah akan memberikan dampak yang lebih besar terhadap pertumbuhan ekonomi karena adanya multiplier berantai ternyata tidak dapat dibuktikan di Sulawesi Selatan.

4. Dalam melakukan model proyeksi PDRB dan APBD berdasarkan hubungan kausalitasnya, maka penggunaan lag 4 menghasilkan model VAR yang paling sesuai.

Rekomendasi yang dapat diberikan sebagai berikut:

1. Hendaknya perencanaan pengeluaran pemerintah lebih difokuskan pada sektor-sektor produktif sehingga dapat mejadi instrumen yang efektif dalam peningkatan dan perluasan kapasitas produksi dan menunjang pertumbuhan ekonomi.

2. Dalam melakukan proyeksi kebutuhan APBD di Sulawesi Selatan, hendaknya memperhatikan variabel ekonomi lainnya, terutama target pencapaian pertumbuhan ekonomi. 


\section{DAFTAR PUSTAKA}

Dornbusch, R, dan Fischer, S, 1987 Makro Ekonomi. Edisi Keempat. Alih Bahasa oleh Mulyadi, J, A, Jakarta: Erlangga.

Hadi, Y. S. 2003, Analisis Vector Autoregressive (VAR) terhadap Korelasi antara Pendapatan Nasional dan Investasi Pemerintah Indonesia, 1983/1984-1999/ 2000; Jurnal Keuangan dan Moneter Volume 6 Nomor 2, Jakarta.

John Loizides dan George Vamvoukas, 2005, Government Expenditure and Economic Growth: Evidence From Trivariate Causality Testing Athens University of Economics And Business; Journal of Applied Economic Volume VIII Nomor 1.

Juanda, B. 2008, Modul Mata Kuliah Ekonometrika Lanjut, Bogor: Program Studi Perencanaan Pembangunan Wilayah dan Perdesaan Sekolah Pascasarjan Institut Pertanian Bogor.

Kuncoro, Mudrajat. 2004. Otonomi dan Pembangunan Daerah: Reformasi, Perencanaan, Strategi dan Peluang. Jakarta: Penerbit Erlangga.

Lin, Justin Yifu dan Zhiqiang Liu. 2000. Fiscal Decentralization and Economic Growth in China, Economic Development and Cultural Change Chicago. Vol. 49. Hal: 1-21.

Mankiw, N, G, 2007, Makroekonomi, Alih Bahasa Liza F dan Nurmawan, I. Edisi Keenam. PT, Jakarta: Gelora Aksara Pratama.

Mardiasmo. 2002. Otonomi dan Manajemen Keuangan Daerah. Yogyakarta: Penerbit Andi.

Nachrowi, N.D. 2006, Pendekatan Populer dan Praktis Ekonometrika untuk Anali- sis Ekonomi dan Keuangan. Jakarta: Lembaga Penerbit Fakultas Ekonomi Universitas Indonesia.

Oates, Wallace E. 1995. Comment on "Conflict and Dillemas of Decentralization" by Rudolf Holmes. The World Bank Research Observer. Hal: 351-353

Pindyck, Rober S. and Daniel L. 1998, Economic Models and Econometric Forecast, $4^{\text {th }}$ edition. New York: N.Y. McGraw Hill.

Saragih, Juli Panglima. 2003. Desentralisasi Fiskal dan Keuangan Daerah dalam Otonomi. Jakarta: Penerbit Ghalia Indonesia.

Verbeck, M., 2000, A Guide Modern Econometrics, Singapore: John Wiley \& Sons, Ltd.

Yustikasari, D.Y., 2007, Pengaruh Pertumbuhan ekonomi, Pendapatan Asli Daerah dan Dana Alokasi Umum terhadap Pengalokasian Anggaran Belanja Modal. Makalah, disampaikan pada Simposium Nasional Akuntansi X, UNHAS Makasar. 